\title{
Rising Divorce Rate Means More Unhappy Marriages?
}

\author{
Kong Lingyu \\ Foreign Languages Department, Inner Mongolia University, China
}

\begin{abstract}
West and China, some people suggest that it means more and more people are having unhappy marriages. But by comparing the Western and Chinese status of marriage and family historically and culturally, the author finds that the opposite is true.
\end{abstract}

Key word:-West, China, marriage, divorce, happy

\section{INTRODUCTION}

Due to the rising divorce rate in recent years, someone argue that leaving the choice of marriage partner to young people not results in happier marriage. However, there is more than one way to look at this issue. Compare western and Chinese concept on gender roles in marriage from tradition to modern, I think actually people are having happier marriage.

\section{TRADITONAL MARRIAGE: THE CONSTRAINING OF PERSONAL FEELINGS}

Traditional marriage in many cases in both the West and China was quite unhappy, but people just constrain their felling and accept it. In the West, marriage was arranged by parents until the $19^{\text {th }}$ century. Under such marriage system, people have no initiative to find their mate. Concerning gender relation, women were in an inferior position in marriage. In Judeo-Christian tradition, women's inferiority began ever since the story ofGenesis in Bible which we are all familiar with. In Genesis, woman was made out of a rib of men." And it was the women who seduced the men to eat the forbidden apple, which result in the fall of men. Under this gender relation, women could never be happy but their needs were neglected and they themselves were dominated by this traditional concept. Marriage traditionally was seen for social and political meaning rather than a personal matter. For instance, according to Xenophon, a famous Greek cavalry leader who studied with Socrates, marriage was first and foremost for the perpetuation oh human being. [1] Personal discontent with marriage was neglected and suppressed. Under Catholicism divorce was discouraged and most Protestants disapproved divorce.As a result, even people feel very unhappy with their marriage, they had to restrain their feeling rather than get divorced to pursue happier marriage. [1] In feudal China, arranged marriage was a common practice and the women were also in an inferiority position. Marriage was considered a clan matter. Parents arrange their children's marriage according to social status, economic condition and family background of the two families. Marriage for a large extent was for the continuation of their family and clan. In Mencius's view "there are three things that are considered as unfilial, and this worst of them is to have no posterity". Women's role in family was to be a good wife and mother. Further they were bound by three obediences and four virtues according to Chinese traditional values, but their personal needs were never considered. Gu HongMIng, a professor in Peking University, said that a true Chinese women has no self. [2] In such feudalistic system full of feudalistic ideas, women rarely had the courage or even the consciousness to get divorced. What their entire feudalistic mind told them was to obey and tolerate.

\section{DIVORCE:PURSUING HAPPIER MARRIAGE}

However, with the change of people's concept on gender roles in modern times, people are having more and more choices, which help to create a favorable environment for happier marriage. With the concept of Romantic Love in the West, people are freed from social retrains and are having more and more freedom and choices of their own in pursuing love and finding their mates. Romantic love, "which encourage individuals to feel they should choose their own marriage partners based on powerful emotional attachment", revolutionized the traditional concept of marriage. [3] People began to feel free to choose their mate according to their own will and marriage is considered their personal fulfillment. People's expectation for marriage is growing. Also women began to be aware of their inferiority and seek egalitarian in family and society. Beginning from the 1960s, the movement of women's liberation first swept America and then soon spread to other western countries. More and more women are determined to change their stereotyped gender role and want full expression of their personal need and right. With the passing of "no-fault divorce" law in the 1970s in America, people are enjoying a more free and democratic atmosphere which granted them with more and more chances for pursuing happy marriage. When they

DOI: $10.9790 / 0837-2108010304 \quad$ www.iosrjournals.org $3 \mid$ Page


find dissatisfaction with their marriage, they think divorce is a better solution to end an unhappy marriage. That's why in the recent years, two-thirds of the divorces have been initiated by women. Similarly, China has also undergone the same change of gender roles and relation. The PRC marriage law of 1950 abolished feudal marriage law and the new marriage system is based on the free choice of partners and on equal rights for both sexes. Gradually, with the passing of law, people's ideology also began to change, feudalistic ideas are abandoned and women are more and more actively involved in working force. Traditional ideas of women's dependence on men are challenged. In the late 1970s, with the implementation of reform and opening policy which enabled the importation of many western ideas, Chinese also are paying more and more attention to individual need. Chinese women had never enjoyed so many free choices than they have now. Divorce becomes a means for them to pursue happier marriage if necessary.

\section{CONCLUSION}

In conclusion, self-consciousness in both the west and China is growing, and women's status in family and society is improving. People are their own master of their marriages. Marriage based on people's own choice and willingness surely leads to happier marriage. The rising divorce rate just shows their higher expectation for marriage and higher self-realization rather than a less happy life..

\section{REFERENCES}

[1] John G. Blair \&Jerusha Hull Mccormack, Western Civilization with Chinese Comparisons, Shanghai:FuDan University Press, 2006,304,320

[2] Guo Hongming The Spirit of Chinese People, BeiJing:Foreign Language Teaching and Research Press, 2011, 205

[3] Howard Gardner, To Open Minds: Chinese Clues to the Dilemmas of Contemporary Education. New York: Basic Books, 1989,18 